\title{
Centennial- to millennial-scale monsoon changes since the last deglaciation linked to solar activities and North Atlantic cooling
}

\author{
Xingxing Liu ${ }^{1,2}$, Youbin Sun ${ }^{1,2,3}$, Jef Vandenberghe ${ }^{4}$, Peng Cheng ${ }^{1,3,5}$, Xu Zhang ${ }^{6,7}$, Evan J. Gowan ${ }^{7}$, \\ Gerrit Lohmann ${ }^{7}$, and Zhisheng $\mathrm{An}^{1,2,3}$ \\ ${ }^{1}$ State Key Laboratory of Loess and Quaternary Geology, Institute of Earth Environment, \\ Chinese Academy of Sciences, Xi' an, 710061, China \\ ${ }^{2}$ CAS Center for Excellence in Quaternary Science and Global Change, Chinese Academy of Sciences, Xi' an, 710061, China \\ ${ }^{3}$ Institute of Global Environmental Change, Xi' an Jiaotong University, Xi'an, 710049, China \\ ${ }^{4}$ Institute of Earth Sciences, Vrije Universiteit, De Boelelaan 1085, 1081 HV Amsterdam, the Netherlands \\ ${ }^{5}$ Shaanxi Key Laboratory of Accelerator Mass \\ Spectrometry Technology and Application, Xi' an AMS Center of IEECAS \& Xi' an University, Xi' an, 710061, China \\ ${ }^{6}$ Key Laboratory of Western China's Environmental Systems (Ministry of Education), College of Earth and Environmental \\ Sciences, Lanzhou University, Lanzhou, 730000, China \\ ${ }^{7}$ Alfred Wegener Institute, Helmholtz Centre for Polar and Marine Research, Bussestraße 24, 27570 Bremerhaven, Germany
}

Correspondence: Xingxing Liu (liuxx@ieecas.cn) and Youbin Sun (sunyb@ieecas.cn)

Received: 14 September 2019 - Discussion started: 7 October 2019

Revised: 27 December 2019 - Accepted: 8 January 2020 - Published: 14 February 2020

\begin{abstract}
Rapid monsoon changes since the last deglaciation remain poorly constrained due to the scarcity of geological archives. Here we present a high-resolution scanning $\mathrm{X}$-ray fluorescence (XRF) analysis of a $13.5 \mathrm{~m}$ terrace succession on the western Chinese Loess Plateau (CLP) to infer rapid monsoon changes since the last deglaciation. Our results indicate that $\mathrm{Rb} / \mathrm{Sr}$ and $\mathrm{Zr} / \mathrm{Rb}$ are sensitive indicators of chemical weathering and wind sorting, respectively, which are further linked to the strength of the East Asian summer monsoon (EASM) and the East Asian winter monsoon (EAWM). During the last deglaciation, two cold intervals of the Heinrich event 1 and Younger Dryas were characterized by intensified winter monsoon and weakened summer monsoon. The EAWM gradually weakened at the beginning of the Holocene, while the EASM remained steady till $9.9 \mathrm{ka}$ and then grew stronger. Both the EASM and EAWM intensities were relatively weak during the Middle Holocene, indicating a mid-Holocene climatic optimum. $\mathrm{Rb} / \mathrm{Sr}$ and $\mathrm{Zr} / \mathrm{Rb}$ exhibit an antiphase relationship between the summer and winter monsoon changes on a centennial timescale during 16-1 ka. Comparison of these monsoon changes with solar
\end{abstract}

activity and North Atlantic cooling events reveals that both factors can lead to abrupt changes on a centennial timescale in the Early Holocene. During the Late Holocene, North Atlantic cooling became the major forcing of centennial monsoon events.

\section{Introduction}

The East Asian monsoon (EAM) is one of the most important atmospheric circulation systems linked to climate changes over high- and low-latitude regions of the Northern Hemisphere (Ding, 1994). It consists of summer and winter monsoons (EASM and EAWM) with significantly seasonal changes in moisture transportation and wind direction. During the past 3 decades, variability in the rain-bearing EASM on a millennial to centennial timescales has been investigated extensively from cave deposits (Dykoski et al., 2005; Wang et al., 2005; and Cheng et al., 2016), loess sequences (An et al., 1991; Ding et al., 1995; Sun et al., 2006, 2016; and Kang et al., 2018), lake sediments (Yancheva et al., 2007; An et al., 2012; Chen et al., 2015; and Liu et al., 2016), ma- 
rine sediments (Huang et al., 2011) and model simulations (Wen et al., 2016). These previous studies show a series of oscillations and/or abrupt events, such as the 4.2, 8.2, 9.2 and $10.3 \mathrm{ka}$ events. These records suggest the summer monsoon variations are not only induced by changes in Northern Hemisphere summer insolation but also strongly modulated by internal land-ocean-air interactions of the Earth-climate systems (e.g., An et al., 2015).

Unlike abundant proxies of the EASM variability, highresolution records reflecting millennial to centennial EAWM variability are still sparse. Though various proxies from different paleoclimatic archives have been used to document EAWM evolution since the last deglaciation, great differences were observed in the inferred winter monsoon changes and forcing mechanisms (Yancheva et al., 2007; Huang et al., 2011; Wang et al., 2012; Li and Morrill, 2015; and Kang et al., 2018). There are four primary factors that contribute to these conflicting records. First, the loess-paleosol record on the Chinese Loess Plateau (CLP) (Sun et al., 2012; Kang et al., 2018) and marine sediments from the South China Sea (Huang et al., 2011) are not of sufficiently high resolution to detect centennial to millennial EAWM changes due to relatively low sedimentation rates. Second, the sensitivity of various archives and proxies to changes in the monsoon intensity is different (e.g., Yancheva et al., 2007; Huang et al., 2011; and Kang et al., 2018). Some environmental proxies commonly show different amplitudes and timing of variation, likely reflecting the fact that they respond to different aspects of climate and environment (temperature, wind and precipitation). Third, the proxies used for the EAWM remain controversial, such as whether titanium (Ti) in Huguang Maar Lake is a proxy for local hydrology or EAWM intensity (Yancheva et al., 2007; Zhang and Lu, 2007). Fourth, uncertain chronologies from diverse natural archives (e.g., loess, lake and marine) may lead to timing mismatch on centennial timescales.

Wen et al. (2016) performed a set of long-term transient simulations that suggest the EASM and EAWM are anticorrelated on millennial timescales in response to North Atlantic meltwater forcing during the last $21 \mathrm{ka}$. However, there is still a lack of high-resolution proxies to support this modeling result. This hampers our understanding of the effects of external solar forcing and internal meltwater feedbacks (Li and Morrill, 2015; Wen et al., 2016). Though numerous studies have focused on the rapid climate changes in the EASM and EAWM since the last deglaciation, significant differences and asynchronous changes still exist (e.g., Wang et al., 2005; Yancheva et al., 2007; Huang et al., 2011; An et al., 2012; and Chen et al., 2015). Therefore, it is crucial to investigate high-resolution, independent proxies with robust chronology of the summer and winter monsoon intensities in one single archive to improve our understanding of rapid monsoon changes and dynamics, in particular the centennial to millennial variability and coherent forcing mechanisms.
In this study, we investigate a thick terrace succession on the western CLP to determine EAWM and EASM variability since the last deglaciation for the first time. Our results provide valuable insights into the relationship between the EAWM and EASM variability at centennial to millennial timescales using high-resolution ( $5 \mathrm{~mm}$ interval) elemental records obtained by X-ray fluorescence (XRF) core scanning. We compare the elemental ratios $(\mathrm{Zr} / \mathrm{Rb}$ and $\mathrm{Rb} / \mathrm{Sr})$ with other paleo-records of abrupt monsoon changes to determine the links with external solar forcing and internal feedbacks.

\section{Materials and methods}

The Dadiwan section (DDW; $35.02^{\circ} \mathrm{N}, 105.8^{\circ} \mathrm{E}$; 1454 ma.s.l) in Qin'an County, Gansu Province, is located on the first terrace of the Wei River on the western CLP (Fig. 1a). Fluvio-eolian sediments are thick and widely deposited on river terraces of the Wei River and its tributaries in this area (Fig. 1b). From 1981 to 2010, the mean annual precipitation and mean annual temperature in Qin' an County are $436.3 \mathrm{~mm}$ and $10.9^{\circ}$, respectively (China Meteorological Administration, 2012). Dadiwan is known as the oldest example and type site of the "Dadiwan cultural" or "Laoguantai cultural" complex, which is the westernmost expression of early millet agriculture in northern China. Previous studies in the Dadiwan area based on organic carbon and pollen revealed that the Middle Holocene is the most humid interval since the last deglaciation (Feng et al., 2004). During April 2015, we retrieved a $13.5 \mathrm{~m}$ core using a hydraulic static drilling rig with a dual-tube (outer and inner tubes) core barrel. The core recovery rate was almost $100 \%$, though some cores were slightly compressed (Fig. 1c).

After splitting the cores into a working and archive half with a Geotek core splitter, the surface of the cores was carefully smoothed to reduce scanning errors caused by irregularities from core slicing (Fig. 1c). The split core surface was subsequently covered with a $4 \mu \mathrm{m}$ Ultralene film during core logging in order to avoid contamination of the XRF detector window and to prevent desiccation of the core surface. The split cores were scanned every $5 \mathrm{~mm}$ using an Avaatech XRF core scanner at the Institute of Earth Environment, Chinese Academy of Sciences. The measured elements ranging from $\mathrm{Al}$ to $\mathrm{Fe}$ in the periodic table were detected at an $\mathrm{X}$ ray voltage of $10 \mathrm{kV}$, Co to Mo were detected at $30 \mathrm{kV}$ and Te to Ba were detected at $50 \mathrm{kV}$ (Richter et al., 2006; Weltje and Tjallingii, 2008). On the basis of the processed model, we used the WinAxil and WinAxilBatch software to calculate the element counts (counts per second, cps) as peak integrals and applied background subtraction. The quality of every single spectrum and peak integral can be easily checked with the $\chi^{2}$ value (Van Espen et al., 1977). As the variation in element concentrations of loess can be related to grain size sorting and chemical weathering (Chen et al., 1999, 2006; 


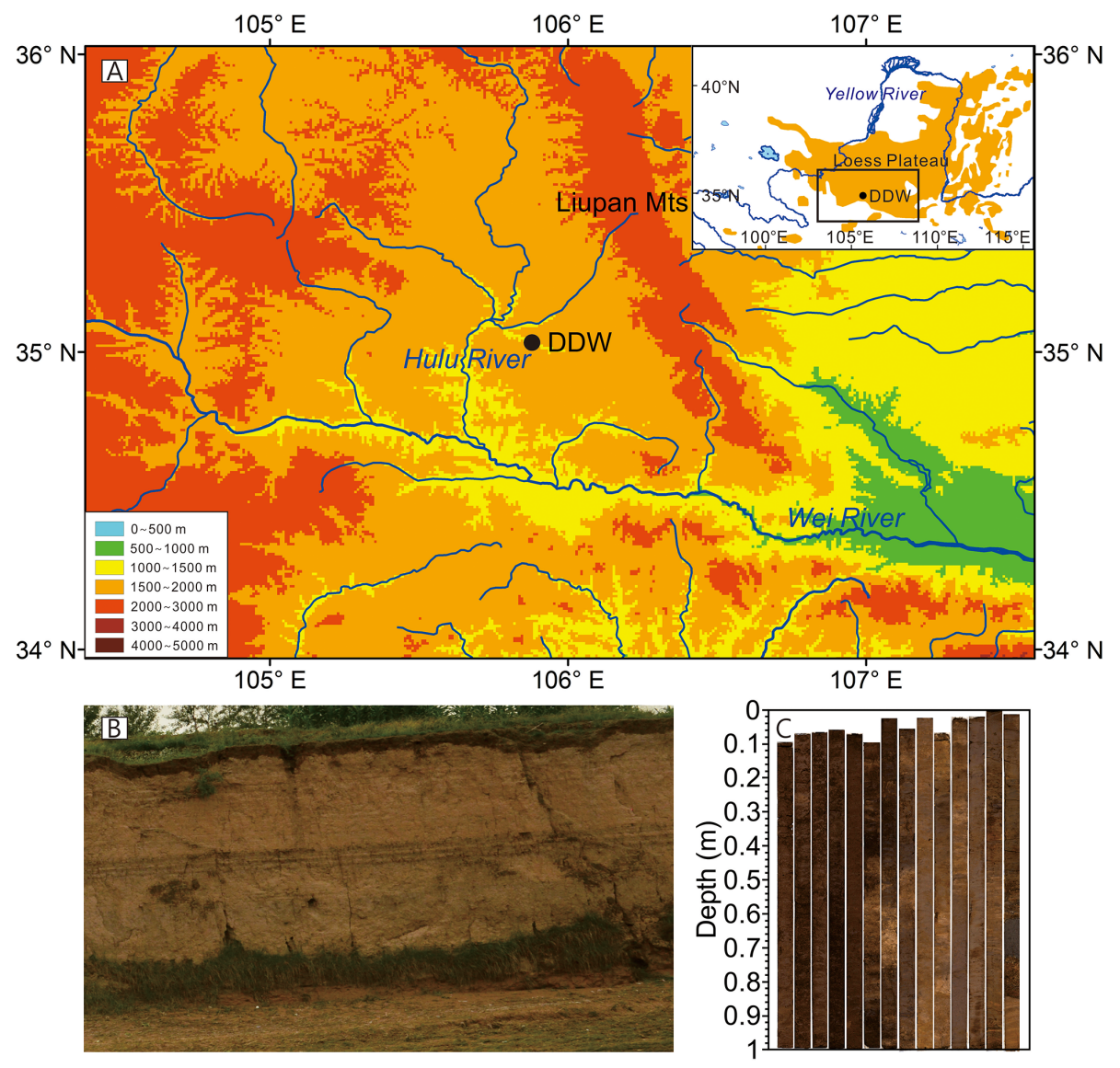

Figure 1. Map showing (a) the CLP and location of the DDW, (b) photographs of DDW terrace outcrop, and (c) cores.

Peng and Guo, 2001), three elements (Rb, $\mathrm{Zr}$ and $\mathrm{Sr}$ ) with high concentrations and low analytical uncertainties which were detected at $30 \mathrm{kV}$ are discussed in this study.

After core scanning, subsamples were taken at contiguous $1 \mathrm{~cm}$ intervals. A total of 1350 subsamples were obtained for grain size and magnetic susceptibility analyses (see Fig. 2 in Liu et al., 2018, for a detailed description). A rough chronology of the DDW section was established by accelerator mass spectrometer (AMS) ${ }^{14} \mathrm{C}$ dates based on five total organic carbon measurements from bulk sediments (Liu et al., 2018). In this study, seven additional ${ }^{14} \mathrm{C}$ dates from bulk organic matter were obtained in order to get more reliable age control. The samples were pretreated with $1 \mathrm{M} \mathrm{HCl}\left(2 \mathrm{~h}, 60^{\circ} \mathrm{C}\right)$ to remove carbonate and then were thoroughly rinsed with distilled water (Zhou et al., 2006). Pretreated samples and $\mathrm{CuO}$ powder were placed into $9 \mathrm{~mm}$ quartz tubes, evacuated to $1 \times 10^{-5}$ Torr and then combusted. The pure $\mathrm{CO}_{2}$ was collected using liquid nitrogen and reduced to graphite for AMS dating. For the AMS analysis, the $\mathrm{CO}_{2}$ was reduced to graphite using $\mathrm{Zn} / \mathrm{Fe}$ catalytic reduction. All of these selected 12 samples were analyzed using a $3 \mathrm{MV}$ tandem accelerator at the Xi' an Accelerated Mass Spectroscopy Center and calibrated using Calib. 7.0.2 (Reimer et al., 2004).

\section{Results}

Based on soil structure, color, magnetic susceptibility and grain size, the $13.5 \mathrm{~m}$ DDW core can be divided lithologically into three subunits from bottom to top as follows: 13$13.5 \mathrm{~m}$, fluvial sediments; $6-13 \mathrm{~m}$, loess deposits; and 0-6 m, paleosol interbedded with four weakly weathered paleosol layers (Fig. 2a). The 12 radiocarbon ages have a linear correlation with depth. This is consistent with a continuous sediment accumulation under a stable environment between 16 and $1 \mathrm{ka}$. The age-depth model is constructed using linear regression $\left(y=1.1465 x+1.2546 ; R^{2}=0.9921\right)$, where $x$ is the depth in meters, and $y$ is the calculated age (Fig. 2b). Since the dating errors range from 24 to 53 years and our $1 \mathrm{~cm}$ sampling strategy yields a time resolution of about 12 years, it is reasonable to discuss centennial- to millennialscale monsoon variations since the last deglaciation based on our high-resolution results.

The magnetic susceptibility displays a stepwise increase from $\sim 13.7 \times 10^{-8} \mathrm{~m}^{3} \mathrm{~kg}^{-1}$ below $6 \mathrm{~m}$ to $15.5-138.6 \times$ $10^{-8} \mathrm{~m}^{3} \mathrm{~kg}^{-1}$ above $6 \mathrm{~m}$, with maximum values at three strongly weathered soil layers (Fig. 2c). Mean grain size, however, exhibits a two-stage variability except for the lower 


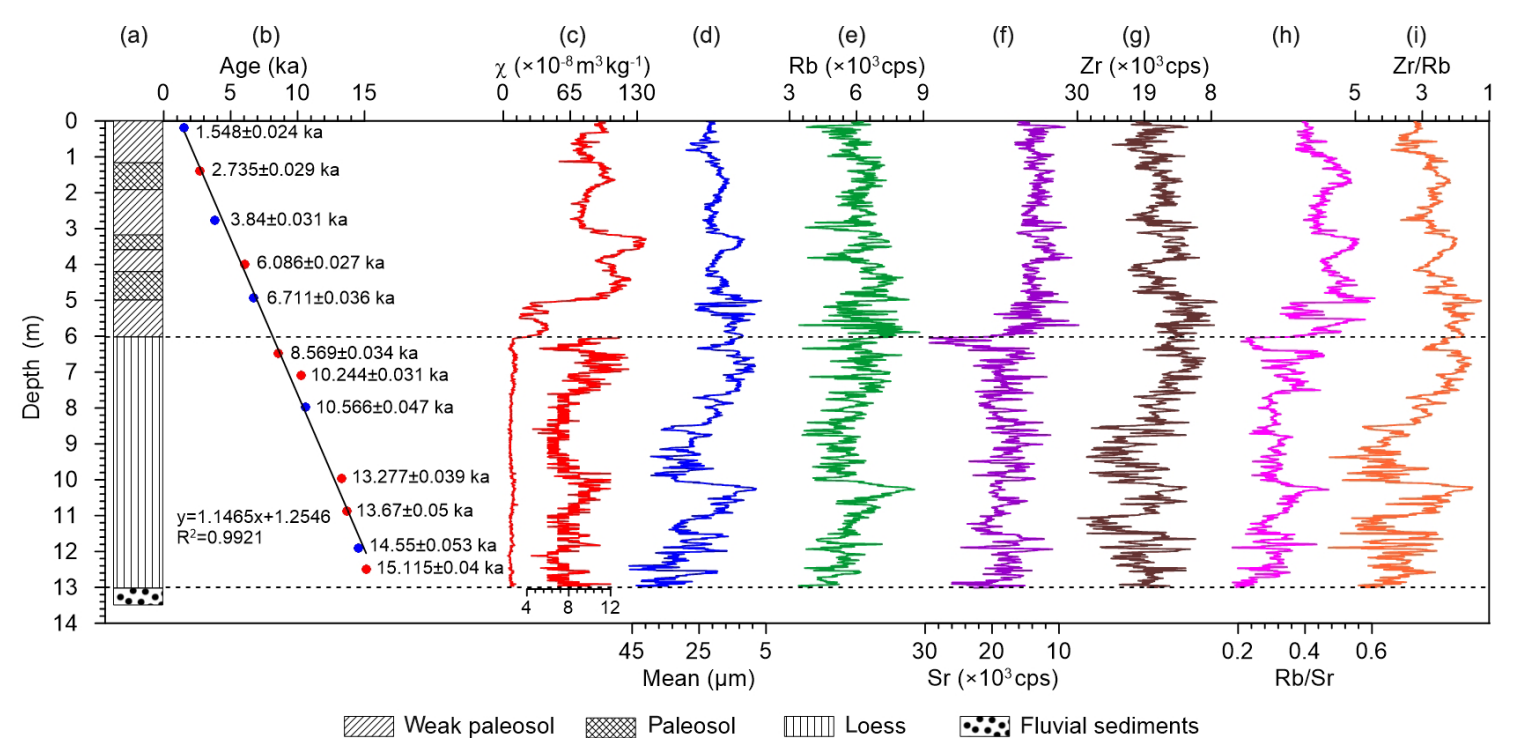

Figure 2. (a) Stratigraphy, (b) age-depth model, (c) magnetic susceptibility, (d) grain-size results and (e-i) elemental results measured by scanning XRF of the DDW core. Five red dots are ages in previous work (Liu et al., 2018). Blue dots are seven additional ages in this study. The elemental results were smoothed with a three-point moving average.

$0.5 \mathrm{~m}$ fluvial sandy layers (not shown here because it goes off the scale) (Fig. 2d); the lower part (13.5-6 m) exhibits large fluctuations $(7.9-121.3 \mu \mathrm{m})$ while the loess-paleosol alternations $(6-0 \mathrm{~m})$ show small fluctuations $(6.4-28.8 \mu \mathrm{m})$. Generally, high magnetic susceptibility corresponds to fine mean grain size, but the abrupt MS increase of around $6 \mathrm{~m}$ is different from the gradual fining of the mean grain size between 8.2 and $6.8 \mathrm{~m}$.

Similar to variations in magnetic susceptibility and grain size, $\mathrm{Rb}, \mathrm{Sr}$ and $\mathrm{Zr}$ exhibit significant variability, with ranges of 3400-8827 cps for Rb (Fig. 2e), 7000-40000 cps for $\mathrm{Sr}$ (Fig. 2f) and 7000-30000 cps for Zr (Fig. 2g). Low Rb/Sr ratio values correspond to low magnetic susceptibility, with values in the range from 0.18 to 0.6 , revealing distinct pedogenic weathering effects (Fig. 2h). The variation in the $\mathrm{Zr} / \mathrm{Rb}$ ratio ranges from 1.2 to 5.8. High $\mathrm{Zr} / \mathrm{Rb}$ ratios occur where grain size is coarse, suggesting grain-size sorting effects (Fig. 2i).

\section{Discussion}

\subsection{EAM variability on an orbital timescale since the last deglaciation}

A number of elements (e.g., Al, Si, K, Ca, Ti, Fe, Mn, Rb, $\mathrm{Zr}$ and $\mathrm{Sr}$ ) based on scanning XRF have been used to acquire information of past climatic and environmental changes (Richter et al., 2006; Liang et al., 2012; and Sun et al., 2016). However, the interpretation of lighter-element data requires careful consideration due to the instrument detection limits and analytical uncertainties (e.g., organic matter and water content) (Richter et al., 2006). Considering the sedimentary characteristics and geochemical behavior of $\mathrm{Zr}$ (commonly abundant in coarse-grained sediments and resistant to weathering), $\mathrm{Rb}$ (enriched in clay deposits; relatively stable) and $\mathrm{Sr}$ (easily mobilized during chemical weathering), the ratios of $\mathrm{Zr} / \mathrm{Rb}$ can be an indicator of grain-size sorting, and $\mathrm{Rb} / \mathrm{Sr}$ is an indicator of chemical weathering (Chen et al., 1999, 2006; Peng and Guo, 2001). Previous studies demonstrated that grain size and magnetic susceptibility of loess-paleosol sequences have been widely used as proxies for winter and summer monsoon, respectively (An et al., 1991; Ding et al., 1995; and Sun et al., 2006). Taking into account that the ratios of $\mathrm{Zr} / \mathrm{Rb}$ and $\mathrm{Rb} / \mathrm{Sr}$ are highly consistent with grainsize and magnetic susceptibility (Fig. 2), we used $\mathrm{Zr} / \mathrm{Rb}$ and $\mathrm{Rb} / \mathrm{Sr}$ ratios as proxies for EAWM and EASM intensity, respectively.

$\mathrm{The} \mathrm{Zr} / \mathrm{Rb}$ and $\mathrm{Rb} / \mathrm{Sr}$ ratios reveal significant millenniumto centennial-scale variability (Fig. 3). During the last deglaciation, the $\mathrm{Zr} / \mathrm{Rb}$ ratio has large-amplitude, highfrequency fluctuations, in contrast to small-amplitude and low-frequency oscillations during the Holocene (Fig. 3b). $\mathrm{The} \mathrm{Rb} / \mathrm{Sr}$ ratio exhibits relatively small-amplitude fluctuations during the last deglaciation to Early Holocene (16$10 \mathrm{ka})$ and the Middle to Late Holocene (7-1 ka). In the Early to Middle Holocene (10-7 ka), there are large-amplitude fluctuations (Fig. 3c). During the last deglaciation, two cold intervals of the Heinrich event 1 (16-14.8 ka) and Younger Dryas (YD; 12.8-11.7 ka) were characterized by intensified EAWM (Fig. 3b) and weakened EASM (Fig. 3c). The period from 14.8 to $12.8 \mathrm{ka}$ with strong EASM/weak EAWM might be temporally consistent with the Bølling-Allerød (BA) warming episode. A rapid weakening of the EAWM occurred during the Early Holocene and then reached a min- 
imum during 9.9-4.8 $\mathrm{ka}$ in the Middle Holocene (Fig. 3b). Minimum EASM intensity occurs from 11.7 to 9.9 ka during the Early Holocene and increased to the highest level during 8-4.8 ka during the Middle Holocene (Fig. 3c). In the Late Holocene, a shift of the monsoon intensity is evident in both $\mathrm{Zr} / \mathrm{Br}$ and $\mathrm{Rb} / \mathrm{Sr}$; EASM continues to moderate while EAWM increased gradually.

On orbital timescales, changes in the EAWM have been linked to changes in ice volume in the Northern Hemisphere (Ding et al., 1995; Liu and Ding, 1998; and Porter, 2001). It has been shown that Northern Hemisphere ice sheets on land were larger during the Early-Middle Holocene than during the Late Holocene (Dyke and Prest, 1987; Kutzbach et al., 1998). The winter insolation in Northern Hemisphere is lower during the Early Holocene than during the Late Holocene (Berger and Loutre, 1991). Such a change in the size of ice sheets and the insolation should have caused a strengthening of the EAWM during the Early Holocene. However, the intensity of EAWM appears to be different between the DDW and the Lake Huguang Maar (Fig. 3a) (Yancheva et al., 2007) in southern China during the Early Holocene. This discrepancy might be attributed to the ice sheets at high latitudes not influencing the EAWM over southern China as strongly as they influenced EAWM expression in northern China during the Early Holocene.

The orbital trend of EASM intensity from DDW generally resembles the pollen-based annual precipitation (PANN) reconstructed from Gonghai Lake (Fig. 3d) (Chen et al., 2015; Liu et al., 2015, 2017), indicating a mid-Holocene climatic optimum (Liu et al., 2015). This suggests that EASM intensity not only follows changes in insolation inferred from the Lake Qinghai summer monsoon index (SMI) (Fig. 3e) (An et al., 2012) and stalagmite $\delta^{18} \mathrm{O}$ records in eastern China (Fig. 3f) (Dykoski et al., 2005; Wang et al., 2005), but also was strongly moderated by the internal feedback processes such as continuous freshwater input into the North Atlantic caused by the remnant melting Laurentide ice sheet (Chen et al., 2015). In addition to this, asynchronous changes among these proxies can be possible due to the varied sensitivity of these proxies and archives to changes in the monsoon intensity (Caley et al., 2014).

\subsection{Centennial monsoon variability since the last deglaciation}

EAWM and EASM intensities are antiphase at both of the millennial and centennial scales since the last deglaciation (Fig. 3). That is, when the EAWM is strong, the EASM is weak. A series of strong EAWM and weak EASM events (e.g., H1, YD, 11.1, 10.1, 9.3, 8.2, 7.3, 6.7, 5.9, 4.6 and $2.1 \mathrm{ka}$ ) can be identified from $\mathrm{Zr} / \mathrm{Rb}$ and $\mathrm{Rb} / \mathrm{Sr}$ values. The mechanism of this antiphase relationship between EAWM and EASM on a millennial to centennial scale can potentially be ascribed to the release of meltwater into the North Atlantic and the resulting change in the Atlantic meridional overturning circulation (AMOC) (Broecker et al., 1992; Alley et al., 1997; Bond et al., 2001; and Wen et al., 2016). In addition, previous studies also suggest that the change in the solar activity partly influences EAWM/EASM strength on a centennial timescale, through the migration of annual mean position of the intertropical convergence zone (ITCZ) during summertime (Haug et al., 2001; Dykoski et al., 2005; Wang et al., 2005; Yancheva et al., 2007; and Steinhilber et al., 2009) and changes in the meridional temperature gradient during wintertime (Xiao et al., 2006; Liu et al., 2009; and Sagawa et al., 2014). However, some of the intervals (e.g., YD, 11.1 and $6.7 \mathrm{ka}$ ) are more distinct in the $\mathrm{Zr} / \mathrm{Rb}$ ratio, while some intervals such as the $7.3 \mathrm{ka}$ event are more distinct in the $\mathrm{Rb} / \mathrm{Sr}$ ratio. The differences between the two proxies records during these abrupt intervals show that they have variable sensitivity to monsoonal wind and precipitation intensity changes (Sun et al., 2012; Chen et al., 2015).

The centennial-scale winter monsoon changes since the last deglaciation reconstructed at DDW are partially consistent with previous high-resolution Ti records from Lake Huguang Maar in southern China (Fig. 3a) (Yancheva et al., 2007). This supports the claim that the record of Ti counts can be a measure of winter monsoon strength although it is still controversial due to the provenance of the lake sediments (Yancheva et al., 2007; Zhang and Lu, 2007). Some of the strong winter monsoon intervals (e.g., $7.3 \mathrm{ka}$ ) are not significant in the Lake Huguang Maar, which indicates that DDW, located in northern China, is more sensitive to the EAWM system. Another possibility for this discrepancy is that control points between 8 and $4 \mathrm{ka}$ are lacking in Lake Huguang Maar (Fig. 3a).

Compared with other summer monsoon proxy records in China, the centennial-scale EASM changes at DDW are consistent with the PANN reconstructed from Gonghai Lake (Fig. 3d) (Chen et al., 2015; Liu et al., 2015, 2017) and SMI from Lake Qinghai (Fig. 3e) (An et al., 2012). Almost all of the weak summer monsoon intervals, within dating errors, appear to coincide with major changes in the PANN reconstruction and SMI. It is worth noting that the $8.2 \mathrm{ka}$ event was not significant in the Gonghai (Fig. 3d) and Qinghai lakes (Fig. 3e). This could be ascribed to age model discrepancies or the variable sensitivity of different proxies to changes in monsoon intensity (Chen et al., 2015). However, there are some discrepancies between the $\mathrm{Rb} / \mathrm{Sr}$ ratio of DDW and the $\delta^{18} \mathrm{O}$ record from Dongge Cave stalagmites in eastern China (Fig. 3f) (Dykoski et al., 2005; Wang et al., 2005). This discrepancy might be attributed to the controversial paleoclimatic significance of $\delta^{18} \mathrm{O}$ records from caves in southern China or the north-south differences for the monsoon intensity (Caley et al., 2014; Tan, 2014; Liu et al., 2015; and Chen et al., 2016). Therefore, the weak EASM intervals existing in all three of these different regions (CLP, northeast of the Tibetan Plateau and eastern China) may have recorded centennial EASM variability since the last deglaciation. 


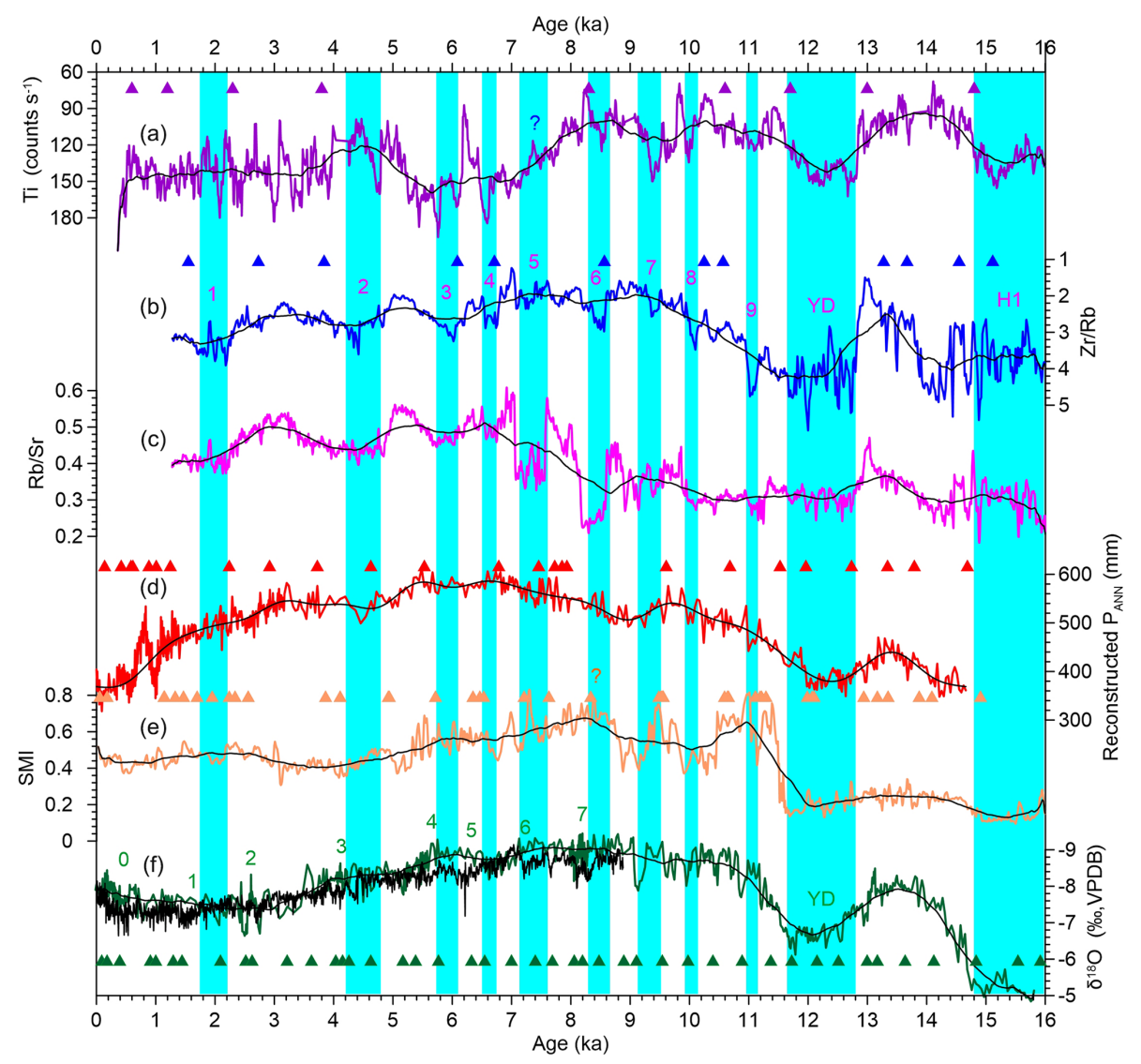

Figure 3. Comparisons of DDW records and other paleoclimatic records. (a) Ti content of Lake Huguang Maar (Yancheva et al., 2007); (b) $\mathrm{Zr} / \mathrm{Rb}$ of DDW core; (c) $\mathrm{Rb} / \mathrm{Sr}$ of DDW core; (d) pollen-based annual precipitation (PANN) reconstructed from Gonghai Lake (Chen et al., 2015); (e) Lake Qinghai summer monsoon index (SMI) (An et al., 2012); (f) speleothem $\delta^{18}$ O from Dongge Cave (Dykoski et al., 2005; Wang et al., 2005). AMS ${ }^{14} \mathrm{C}$ ages are marked on the records of Lake Huguang Maar (purple triangle), DDW (blue triangle), Gonghai Lake (red triangle) and Lake Qinghai (peach triangle). The ${ }^{230}$ Th ages (green triangle) are shown on the speleothem records. The cyan bars indicate the timing of abrupt monsoon events in different records.

\subsection{Links between solar forcing and high-latitude climate changes}

We removed the long-term trend of $\mathrm{Zr} / \mathrm{Rb}$ and $\mathrm{Rb} / \mathrm{Sr}$ ratios to investigate the high-frequency components of the signal $(<1 \mathrm{kyr})$, then compared the results with the North Atlantic hematite-stained grains records (HSG) (Bond et al., 2001) and atmospheric ${ }^{14} \mathrm{C}$ production rate $\left({ }^{14} \mathrm{C}\right)$ (Reimer et al., 2013) (Fig. 4a-d). HSG is a tracer of drift ice in the North Atlantic; high values of HSG indicate cold conditions (Bond et al., 2001). Higher values of atmospheric ${ }^{14} \mathrm{C}$ represent weak solar activity and vice versa (Stuiver and Quay, 1980). High-frequency components of the EAWM (Fig. 4e-h) and EASM (Fig. 4i-l) proxies from DDW exhibit large-amplitude fluctuations during the Early Holocene (11.5-7 ka), while the amplitude variations were more moderate during the Late Holocene ( $7-1 \mathrm{ka}$ ), especially the $\mathrm{Rb} / \mathrm{Sr}$ ratio. All of the strong winter and weak summer monsoon intervals from DDW records can either be correlated with HSG (Fig. 4a) or with high atmospheric ${ }^{14} \mathrm{C}$ (Fig. 4d). This indicates a possible relationship with Northern Hemisphere cooling and solar activity.

During the Early Holocene (11.5-7 ka), all of the strong EAWM/weak EASM intervals (e.g., 11.1, 10.1, 9.3, 8.2 and $7.3 \mathrm{ka}$ ) within the limits of dating error are correlated with HSG (Fig. 4a) and high ${ }^{14} \mathrm{C}$ (Fig. 4d). High similarity of these records suggests that the North Atlantic cooling events and solar activity probably simultaneously affect the EAM systems on centennial timescales. During the Late Holocene (7-1 ka), all of the strong EAWM (Fig. 4e-f) and weak EASM (Fig. 4i-1) events (e.g., 6.7, 5.9, 4.6, 3.3, 2.8 and $2.1 \mathrm{ka})$ correspond well to the abrupt events in the North Atlantic region. This indicates that North Atlantic cooling plays an important role in driving the centennial monsoon changes during the Late Holocene. The 3.3 and 2.8 ka events are also correlated well with high ${ }^{14} \mathrm{C}$, which indicates solar forcing also plays a role during those times.

In order to further confirm the possible link of monsoon variability with internal North Atlantic feedbacks and ex- 

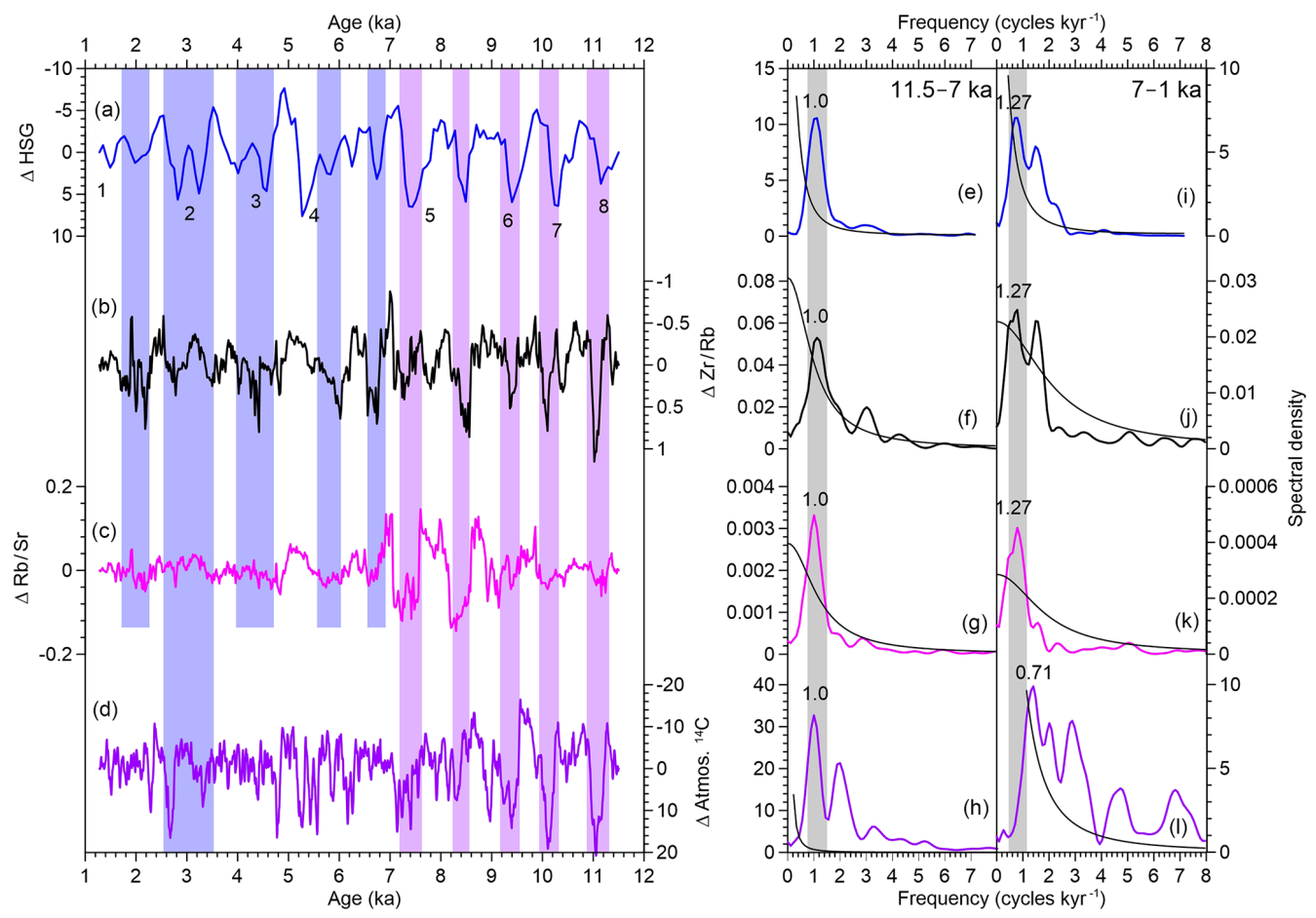

Figure 4. (a-d) Centennial components of (b) $\mathrm{Zr} / \mathrm{Rb}$ and (c) $\mathrm{Rb} / \mathrm{Sr}$ with (a) the North Atlantic HSG (Bond et al., 2001) and (d) atmosphere ${ }^{14} \mathrm{C}$ record (Reimer et al., 2013). The purple and blue bars indicate abrupt monsoon events. Plots (e-l) show the spectra of the proxy records during the (e-h) Early and (i-l) Late Holocene. Spectral peaks that are above the $80 \%$ confidence levels (black lines) are marked. The grey vertical bands indicate the most significant cycle.

ternal solar forcing on a centennial scale, spectral analyses were conducted on these proxies for the Early $(11.5-7 \mathrm{ka})$ (Fig. 4e-h) and Late (7-1 ka) (Fig. 4i-l) Holocene (Fig. 4). The spectral results reveal that the $\mathrm{Zr} / \mathrm{Rb}$ and $\mathrm{Rb} / \mathrm{Sr}$ records both display a prominent periodicity at $1.0 \mathrm{kyr}$ (Fig. $4 \mathrm{f}$ and g). This matches with the cycle of HSG (Fig. 4e) and ${ }^{14} \mathrm{C}$ (Fig. 4h) during the Early Holocene. The similarity in periodicity further confirms the link of centennial EAM variability to North Atlantic cooling and solar activities during the Early Holocene (11.5-7 ka). However, the dominant periodicity $(\sim 1.27 \mathrm{kyr})$ of $\mathrm{HSG}, \mathrm{Zr} / \mathrm{Rb}$ and $\mathrm{Rb} / \mathrm{Sr}$ records is not evident in the ${ }^{14} \mathrm{C}$ spectrum during the Late Holocene (7-1 ka) (Fig. 4i-1), implying that solar forcing is not the dominant cause of centennial monsoon variability during this period.

North Atlantic cooling and solar activity are two commonly accepted drivers of centennial climate variability. There is a teleconnection between rapid monsoon changes and abrupt events in the North Atlantic region (the ocean thermohaline circulation) (Broecker et al., 1992; Alley et al., 1997; Bond et al., 2001; and Wang et al., 2005). The strength of the Siberian High, located north of our DDW section, increases when the North Atlantic is in a cold mode (Gong et al., 2001). The ITCZ shifted southward due to changes in the AMOC and temperature gradients across the Northern Hemisphere. When ITCZ shifted southward, the
EASM weakened and the EAWM strengthened (Broccoli et al., 2006; Sun et al., 2012; and Wen et al., 2016). Speleothem records from China (Dykoski et al., 2005; Cheng et al., 2006; and Wang et al., 2005) and many model simulations (Chiang and Bitz, 2005; Broccoli et al., 2006) support this.

The change in solar activity could contribute to the regional monsoon variability by affecting low-latitude hydrological processes (Liu et al., 2009; Yan et al., 2015). Specifically, decreased summer insolation results in changes to the land-ocean thermal contrast. The sea surface temperature in the western tropical Pacific decreases and the northwest Pacific subtropical high weakens (Liu et al., 2003; Cai et al., 2010). This decreased thermal contrast would result in a southward migration of the ITCZ and also weaken the EASM strength by reducing the monsoon moisture transport from the tropical ocean to the continent at low latitudes (Liu et al., 2009; Yan et al., 2015). Since changes in solar output are large at the centennial scale during the Early Holocene, this may amplify the solar output effect due to nonlinear responses and feedback processes of the climate system (Mohtadi et al., 2016). During the Late Holocene (7-1 ka), there is a decrease in summer insolation and the small-amplitude fluctuations of solar activities (Fig. 4d) (Berger, 1978). This is probably why it plays a less important role in the EAM system. 


\section{Conclusions}

We recovered a high-resolution last deglaciation record of EAWM and EASM from terrace sediments on the western CLP. Ratios of $\mathrm{Zr} / \mathrm{Rb}$ and $\mathrm{Rb} / \mathrm{Sr}$ are sensitive indicators of winter wind intensity and chemical weathering, respectively, and thus can be regarded as an index of EAWM and EASM. In general, the ratios of $\mathrm{Rb} / \mathrm{Sr}$ and $\mathrm{Zr} / \mathrm{Rb}$ display significant fluctuation similar to the global climate characteristics since the last deglaciation (16-1 ka), such as the Heinrich cooling (H1), Bølling-Allerød warming and Younger Dryas cooling events. Both EAWM and EASM show Holocene optimum during the Middle Holocene. A number of strong and weak monsoon changes are identified by means of $\mathrm{Zr} / \mathrm{Rb}$ and $\mathrm{Rb} / \mathrm{Sr}$ values from DDW, such as strong EAWM/weak EASM intervals around H1, YD, 11.1, 10.1, 9.3, 8.2, 5.9, 4.6, 3.3, 2.8 and $2.1 \mathrm{ka}$, which reveal a negative co-variability between the EAWM and EASM on a centennial timescale. Our $\mathrm{Zr} / \mathrm{Rb}$ and $\mathrm{Rb} / \mathrm{Sr}$ records are consistent with the Ti content from Lake Huguang Maar (EAWM proxy), the PANN reconstructed from Gonghai Lake and the SMI from Lake Qinghai (both EASM proxies). Comparing with North Atlantic cooling and solar activity proxies, our record shows that both are possible driving factors of centennial monsoon variability. North Atlantic cooling events and solar activity are the dominant forcing of the EAM system during the Early Holocene, while North Atlantic cooling became more important during the Late Holocene.

Data availability. All data are accessible from the authors. Correspondence and requests for materials should be addressed to Xingxing Liu(liuxx@ieecas.cn).

Author contributions. XL and YS designed the study and performed the fieldwork and experiments. JV and XZ contributed to data analysis. PC conducted the AMS ${ }^{14} \mathrm{C}$ analysis. EJG, GL and ZA improved the paper with their contributions.

Competing interests. The authors declare that they have no conflict of interest.

Acknowledgements. Two anonymous reviewers are acknowledged for their valuable suggestions. We thank Hu Yang, Long Ma and Haijiao Liu for their helpful discussions. We also thank Hua Wang and Min Zhao for field and laboratory assistance.

Financial support. This research has been supported by the The National Key Research and Development Program of China (grant no. 2016YFA0601902), the The National Science Foundation for Young Scientists of China (grant no. 41807425), the The National Science Foundation of China (grant no. 41525008) and the The
Open Foundation of State Key Laboratory of Loess and Quaternary Geology (grant no. SKLLQG1633).

Review statement. This paper was edited by Qiuzhen Yin and reviewed by two anonymous referees.

\section{References}

Alley, R. B., Mayewski, P. A., Sowers, T., Stuiver, M., Taylor, K. C., and Clark, P. U.: Holocene climatic instability: A prominent, widespread event 8200 yr ago, Geology, 25, 483-486, 1997.

An, Z. S., Kukla, G., Porter, S. C., and Xiao, J. L.: Late Quaternary dust flow on the Chinese loess plateau, Catena, 18, 125-132, 1991.

An, Z. S., Colman, S. M., Zhou, W. J., Li, X. Q., Brown, E. T., Jull, A. J. T., Cai, Y. J., Huang, Y. S., Lu, X. F., Chang, H., Song, Y. G., Sun, Y. B., Xu, H., Liu, W. G., Jin, Z. D., Liu, X. D., Cheng, P., Liu, Y., Ai, L., Li, X. Z., Liu, X. J., Yan, L. B., Shi, Z. G., Wang, X. L., Wu, F., Qiang, X. K., Dong, J. B., Lu, F. Y., and Xu, X. W.: Interplay between the Westerlies and Asian monsoon recorded in Lake Qinghai sediments since $32 \mathrm{ka}$, Scientific Reports, 2, 619, 2012.

An, Z. S., Wu, G. X., Li, J. P., Sun, Y. B., Liu, Y. M., Zhou, W. J., Cai, Y. J., Duan, A. M., Li, L., Mao, J. Y., Cheng, H., Shi, Z. G., Tan, L. C., Yan, H., Ao, H., Chang, H., and Juan, F.: Global Monsoon Dynamics and Climate Change, Annu. Rev. Earth Pl. Sc., 43, 29-77, 2015.

Berger, A.: Long term variations of daily insolations and quaternary climatic changes, J. Atmos. Sci., 35, 2362-2367, 1978.

Berger, A. and Loutre, M. F.: Insolation values for the climate of the last 10 million years, Quaternary Sci. Rev., 10, 297-317, 1991.

Bond, G., Kromer, B., Beer, J., Muscheler, R., Evans, M.N., Showers,W., Hoffmann, S., Lotti Bond, R., Hajdas, I., and Bonani, G.: Persistent solar influence on North Atlantic climate during the Holocene, Science, 294, 2130-2136, 2001.

Broccoli, A. J., Dahl, K. A., and Stouffer, R. J.: Response of the ITCZ to Northern Hemisphere cooling, Geophys. Res. Lett., 33, L01702, https://doi.org/10.1029/2005GL024546, 2006.

Broecker, W., Bond, G., Klas, M., Clark, E., and McManus, J.: Origin of the northern Atlantic's Heinrich events, Clim. Dynam., 6, 265-273, 1992.

Cai, Y. J., Tan, L. C., Cheng, H., An, Z. S., Edwards, R. L., Kelly, M. J., Kong, X. G., and Wang, X. F.: The variation of summer monsoon precipitation in Central China since the last deglaciation, Earth Planet. Sc. Lett., 291, 21-31, 2010.

Caley, T., Roche, D. M., and Renssen, H.: Orbital Asian summer monsoon dynamics revealed using an isotopeenabled global climate model, Nat. Communications, 5, 5371, https://doi.org/10.1038/ncomms6371, 2014.

Chen, F., Xu, Q., Chen, J., Birks, H. J. B., Liu, J., Zhang, S., Jin, L., An, C., Telford, R. J., Cao, X., Wang, Z., Zhang, X., Selvaraj, K., Lu, H., Li, Y., Zheng, Z., Wang, H., Zhou, A., Dong, G., Zhang, J., Huang, X., Bloemendal, J., and Rao, Z.: East Asian summer monsoon precipitation variability since the last deglaciation, Scientific Reports, 5, 11186, https://doi.org/10.1038/srep11186, 2015 . 
Chen, J., An, Z. S., Wang, Y. J., Ji, J. F., Chen, Y., and Lu, H. Y.: Distribution of $\mathrm{Rb}$ and $\mathrm{Sr}$ in the Luochuan loess-paleosal sequence of China during the last 800 kaimplications for paleomonsoon variations, Science China Earth Sciences, 42, 225-232, 1999.

Chen, J., Chen, Y., Liu, L., Ji, J., Balsam, W., Sun, Y., and Lu, H.: $\mathrm{Zr} / \mathrm{Rb}$ ratio in the Chinese loess sequences and its implication for changes in the East Asian winter monsoon strength, Geochim. Cosmochim. Ac., 70, 1471-1482, 2006.

Chen, J. H., Rao, Z. G., Liu, J. B., Huang, W., Feng, S., Dong, G. H., Hu, Y., Xu, Q. H., Chen, F. H.: On the timing of the East Asian summer monsoon maximum during the HoloceneDoes the speleothem oxygen isotope record reflect monsoon rainfall variability?, Science China Earth Sciences, 59, 23282338, 2016.

Cheng, H., Edwards, R. L., Wang, Y., Kong, X., Ming, Y., Kelly, M. J., Wang, X. F., Gallup, C. D., and Liu, W. G.: A penultimate glacial monsoon record from Hulu Cave and two-phase glacial terminations, Geology, 34, 217-220, 2006.

Cheng, H., Edwards, R. L., Sinha, A., Spotl, C., Yi, L., Chen, S. T., Kelly, M., Kathayat, G., Wang, X. F., Li, X. L., Kong, X. G., Wang, Y. J., Ning, Y. F., and Zhang, H. W.: The Asian monsoon over the past 640,000 years and ice age terminations, Nature, 534, 640-646, 2016.

Chiang, J. C. H. and Bitz, C. M.: Influence of high latitude ice cover on the marine Intertropical Convergence Zone, Clim. Dynam., 25, 477-496, 2005.

China Meteorological Administration: Dataset of daily surface observation values in individual years (1981-2010) in China, available at: http://data.cma.cn/en/?r=data/detail\&dataCode=A.0029. 0001 (last access: 2 February 2020), 2012.

Ding, Y. H.: Monsoons over China, Dordrecht, Kluwer Academic, Netherlands, 419 pp., 1994.

Ding, Z. L., Liu, T. S., Rutter, N. W., Yu, Z. W., Guo, Z. T., and Zhu, R. X.: Ice-volume forcing of East Asian winter monsoon variations in the past 800,000 years, Quaternary Res., 44, 149159, 1995.

Dyke, A. and Prest, V.: Late Wisconsinan and Holocene history of the Laurentide ice sheet, Geogr. Phys. Quatern., 41, 237-263, 1987.

Dykoski, C. A., Edwards, R. L., Cheng, H., Yuan, D. X., Cai, Y. J., Zhang, M. L., Liu, Y. S., Qing, J. M., An, Z. S., and Revenaugh, J.: A high-resolution, absolute-dated Holocene and deglacial Asian monsoon record from Dongge cave, China, Earth Planet. Sc. Lett., 233, 71-86, 2005.

Feng, Z. D., An, C. B., Tang, L. Y., and Jull, A. J. T.: Stratigraphic evidence of a Megahumid climate between 10,000 and 4000 years BP in the western part of the Chinese Loess Plateau, Global Planet. Change, 43, 145-155, 2004.

Gong, D. Y., Wang, S. W., and Zhu, J. H.: East Asian winter monsoon and Arctic Oscillation, Geophys. Res. Lett., 28, 2073-2076, 2001.

Haug, G. H., Hughen, K. A., Sigman, D. M., Peterson, L. C., and Röhl, U.: Southward migration of the intertropical convergence zone through the Holocene, Science, 293, 1304-1308, 2001.

Huang, E., Tian, J., and Steinke, S.: Millennial-scale dynamics of the winter cold tongue in the southern South China Sea over the past $26 \mathrm{ka}$ and the East Asian winter monsoon, Quaternary Res., 75, 196-204, 2011.
Kang, S. G., Wang, X. L., Roberts, H. M., Duller, G. A., Cheng, P., Lu, Y. C., and An, Z. S.: Late Holocene anti-phase change in the East Asian summer and winter monsoons, Quaternary Sci. Rev., 188, 28-36, 2018.

Kutzbach, J., Gallimore, R., Harrison, S., Behlinga, P., Selina, R., and Laarif, F.: Climate and biome simulations for the past 21,000 years, Quaternary Sci. Rev., 17, 473-506, 1998.

Li, Y. and Morrill, C.: A Holocene East Asian winter monsoon record at the southern edge of the Gobi Desert and its comparison with a transient simulation, Clim. Dynam., 45, 1219-1234, 2015.

Liang, L. J., Sun, Y. B., Yao, Z. Q., Liu, Y. G., and Wu, F.: Evaluation of high-resolution elemental analyses of Chinese loess deposits measured by X-ray fluorescence core scanner, Catena, 92, 75-82, 2012.

Liu, J., Wang, B., Ding, Q., Kuang, X., Soon, W., and Zorita, E.: Centennial variations of the global monsoon precipitation in the last millennium: results from ECHO-G model, J. Climate, 22, 2356-2371, 2009.

Liu, J. B., Chen, J. H., Zhang, X. J., Li, Y., Rao, Z. G., and Chen, F. H.: Holocene East Asian summer monsoon records in northern China and their inconsistency with Chinese stalagmite $\delta^{18} \mathrm{O}$ records, Earth-Sci. Rev., 148, 194-208, 2015.

Liu, J. B., Rühland, K. M., Chen, J. H., Xu, Y. Y., Chen, S. Q., Chen, Q. M., Huang, W., Xu, Q. H., Chen, F. H., and Smol, J. P.: Aerosol-weakened summer monsoons decrease lake fertilization in the Chinese Loess Plateau, Nat. Clim. Change, 7, 190-194, 2017.

Liu, T. and Ding, Z.: Chinese loess and the paleomonsoon, Annu. Rev. Earth Pl. Sc., 26, 111-145, 1998.

Liu, X. Q., Dong, H. L., Yang, X. D., Herzschuh, U., Zhang, E. L., Stuut, J.-B. W., and Wang, Y. B.: Late Holocene forcing of the Asian winter and summer monsoon as evidenced by proxy records from the northern Qinghai-Tibetan Plateau, Earth Planet. Sc. Lett., 280, 276-284, 2009.

Liu, X. X., Vandenberghe, J., An, Z. S., Li, Y., Jin, Z. D., Dong, J. B., and Sun, Y. B.: Grain size of Lake Qinghai sediments: implications for riverine input and Holocene monsoon variability, Palaeogeogr. Palaeocl., 449, 41-51, 2016.

Liu, X. X., Sun, Y. B., Vandenberghe, J., Li, Y., and An, Z.: Palaeoenvironmental implication of grain-size compositions of terrace deposits on the western Chinese Loess Plateau, Aeolian Res., 32, 202-209, 2018.

Liu, Z., Otto-Bliesner, B., Kutzbach, J., Li, L., and Shields, C.: Coupled climate simulation of the evolution of global monsoons in the Holocene, J. Climate, 16, 2472-2490, 2003.

Mohtadi, M., Prange, M., and Steinke, S.: Palaeoclimatic insights into forcing and response of monsoon rainfall, Nature, 533, 191199, 2016.

Peng, S. Z. and Guo, Z. T.: Geochemical indicator of original eolian grain size and implications on winter monsoon evolution, Sci. China Ser. D, 44, 261-266, 2001.

Porter, S. C.: Chinese loess record of monsoon climate during the last glacial-interglacial cycle, Earth-Sci. Rev., 54, 115-128, 2001.

Reimer, P. J., Baillie, M. G. L., Bard, E., Bayliss, A., Beck, J. W., Bertrand, C. J. H., Blackwell, P. G., Buck, C. E., Burr, G. S., Cutler, K. B., Damon, P. E., Edwards, R. L., Fairbanks, R. G., Friedrich, M., Guilderson, T. P., Hogg, A. G., Hughen, K. A., 
Kromer, B., McCormac, G., Manning, S., Ramsey, C. B., Reimer, R. W., Remmele, S., Southon, J. R., Stuiver, M., Talamo, S., Taylor, F. W., van der Plicht, J., and Weyhenmeyer, C. E.: IntCal04 terrestrial radiocarbon age calibration, 0-26 cal kyr BP, Radiocarbon, 46, 1029-1058, 2004.

Reimer, P. J., Bard, E., Bayliss, A., Beck, J. W., Blackwell, P. G., Bronk Ramsey, C., Buck, C. E., Cheng, H., Edwards, R. L., and Friedrich, M.: IntCal13 and Marine13 radiocarbon age calibration curves $0-50,000$ years cal BP, Radiocarbon, 55, 1869-1887, 2013.

Richter, T. O., Van der Gaast, S., Koster, B., Vaars, A., Gieles, R., de Stigter, H. C., Haas, H. D., and van Weering, T. C.: The Avaatech XRF Core Scanner: technical description and applications to NE Atlantic sediments, Geological Society, London, Special Publications, 267, 39-50, 2006.

Sagawa, T., Kuwae. M., Tsuruoka, K., Nakamura, Y., Ikehara, M., and Murayama, M.: Solar forcing of centennial-scale East Asian winter monsoon variability in the mid-to late Holocene, Earth Planet. Sc. Lett., 395, 124-135, 2014.

Steinhilber, F., Beer, J., and Fröhlich, C.: Total solar irradiance during the Holocene, Geophys. Res. Lett., 36, L19704, https://doi.org/10.1029/2009GL040142, 2009.

Stuiver, M. and Quay, P. D.: Changes in atmospheric carbon-14 attributed to a variable sun, Science, 207, 11-19, 1980.

Sun, Y. B., Chen, J., Clemens, S. C., Liu, Q. S., Ji, J. F., and Tada, R.: East Asian monsoon variability over the last seven glacial cycles recorded by a loess sequence from the northwestern Chinese Loess Plateau, Geochem. Geophy. Geosy., 7, Q12Q02, https://doi.org/10.1029/2006GC001287, 2006.

Sun, Y. B., Clemens, S. C., Morrill, C., Lin, X. P., Wang, X. L., and An, Z. S.: Influence of Atlantic meridional overturning circulation on the East Asian winter monsoon, Nat. Geosci., 5, 46-49, 2012.

Sun, Y. B., Liang, L. J., Bloemendal, J., Li, Y., Wu, F., Yao, Z. Q., and Liu, Y. G.: High-resolution scanning XRF investigation of Chinese loess and its implications for millennial-scale monsoon variability, J. Quaternary Sci., 31, 191-202, 2016.

Tan, M.: Circulation effect: response of precipitation $\delta^{18} \mathrm{O}$ to the ENSO cycle in monsoon regions of China, Clim. Dynam., 42, 1067-1077, 2014.
Van Espen, P., Nullens, H., and Adams, F.: A computer analysis of X-ray fluorescence spectra, Nucl. Instrum. Methods, 142, 243250, 1977.

Wang, L., Li, J. J., Lu, H. Y., Gu, Z. Y., Rioual, P., Hao, Q. Z., Mackay, A. W., Jiang, W. Y., Cai, B. G., Xu, B., Han, J. T., and Chu, G. Q.: The East Asian winter monsoon over the last 15,000 years: its links to high-latitudes and tropical climate systems and complex correlation to the summer monsoon, Quaternary Sci. Rev., 32, 131-142, 2012.

Wang, Y. J., Cheng, H., Edwards, R. L., He, Y., Kong, X., An, Z. S., Wu, J., Kelly, M. J., Dykoski, C. A., and Li, X.: The Holocene Asian monsoon: links to solar changes and North Atlantic climate, Science, 308, 854-857, 2005.

Weltje, G. J. and Tjallingii, R.: Calibration of XRF core scanners for quantitative geochemical logging of sediment cores: theory and application, Earth Planet. Sc. Lett., 274, 423-438, 2008.

Wen, X. Y., Liu, Z. Y., Wang, S. W., Cheng, J., and Zhu, J.: Correlation and anticorrelation of the East Asian summer and winter monsoons during the last 21,000 years, Nat. Commun., 7, 11999, https://doi.org/10.1038/ncomms11999, 2016.

Xiao, S. B., Li, A. C., Liu, J. P., Chen, M. H., Xie, Q., Jiang, F. Q., Li, T. G., Xiang, R., and Chen, Z.: Coherence between solar activity and the East Asian winter monsoon variability in the past 8000 years from Yangtze River-derived mud in the East China Sea, Palaeogeogr. Palaeocl., 237, 293-304, 2006.

Yan, H., Soon, W., and Wang, Y.: A composite sea surface temperature record of the northern South China Sea for the past 2500 years: a unique look into seasonality and seasonal climate changes during warm and cold periods, Earth-Sci. Rev., 141, 122-135, 2015.

Yancheva, G., Nowaczyk, N. R., Mingram, J., Dulski, P., Schettler, G., Negendank, J. F. W., Liu, J., Sigman, D. M., Peterson, L. C., and Haug, G. H.: Influence of the intertropical convergence zone on the East Asian monsoon, Nature, 445, 74-77, 2007.

Zhang, D. E. and Lu, L.: Anti-correlation of summer/winter monsoons?, Nature, 450, E7-E8, 2007.

Zhou, W. J., Zhao, X. L., Lu, X. F., Liu, L., Wu, Z. K., Cheng, P., Zhao, W. N., and Huang, C. H.: The 3MV multi-element AMS in Xi' an, China: unique features and preliminary tests, Radiocarbon, 48, 285-293, 2006. 